University of Wollongong

Research Online

Faculty of Engineering and Information

Faculty of Engineering and Information

Sciences - Papers: Part A

Sciences

January 2014

Oxidation reduction potential as a parameter to regulate micro-oxygen injection into anaerobic digester for reducing hydrogen sulphide concentration in biogas

Long D. Nghiem

University of Wollongong, longn@uow.edu.au

Patrick Manassa

University of Wollongong, patrie@uow.edu.au

Marcia Dawson

Sydney Water Corporation

Shona K. Fitzgerald

Sydney Water Corporation

Follow this and additional works at: https://ro.uow.edu.au/eispapers

Research Online is the open access institutional repository for the University of Wollongong. For further information contact the UOW Library: research-pubs@uow.edu.au 


\title{
Oxidation reduction potential as a parameter to regulate micro-oxygen injection into anaerobic digester for reducing hydrogen sulphide concentration in biogas
}

\begin{abstract}
This study aims to evaluate the use of oxidation reduction potential (ORP) to regulate the injection of a small amount of oxygen into an anaerobic digester for reducing $\mathrm{H} 2 \mathrm{~S}$ concentration in biogas. The results confirm that micro-oxygen injection can be effective for controlling $\mathrm{H} 2 \mathrm{~S}$ formation during anaerobic digestion without disturbing the performance of the digester. Biogas production, composition, and the removal of volatile solids (VS) and chemical oxygen demand (COD) were monitored to assessment the digester's performance. Six days after the start of the micro-oxygen injection, the ORP values increased to between -320 and $-270 \mathrm{mV}$, from the natural baseline value of $-485 \mathrm{mV}$. Over the same period the $\mathrm{H} 2 \mathrm{~S}$ concentration in the biogas decreased from over $6000 \mathrm{ppm}$ to just $30 \mathrm{ppm}$. No discernible changes in the VS and COD removal rates, $\mathrm{pH}$ and alkalinity of the digestate or in the biogas production or composition were observed.
\end{abstract}

\section{Keywords}

regulate, micro, oxygen, injection, into, anaerobic, digester, reducing, hydrogen, oxidation, sulphide, reduction, concentration, biogas, potential, parameter

\section{Publication Details}

Nghiem, L. D., Manassa, P., Dawson, M. \& Fitzgerald, S. K. (2014). Oxidation reduction potential as a parameter to regulate micro-oxygen injection into anaerobic digester for reducing hydrogen sulphide concentration in biogas. Bioresource Technology, 173 443-447. 


\section{Oxidation Reduction Potential as a Parameter to Regulate Micro-Oxygen Injection into Anaerobic Digester for Reducing Hydrogen Sulphide Concentration in Biogas}

\section{Revised Manuscript Submitted to \\ Bioresource Technology}

Sep 2014

Long D. Nghiem ${ }^{\mathrm{a}, *}$, Patrick Manassa ${ }^{\mathrm{a}}$, Marcia Dawson ${ }^{\mathrm{b}}$, and Shona K. Fitzgerald ${ }^{\mathrm{b}}$

${ }^{\text {a }}$ Strategic Water Infrastructure Laboratory, School of Civil Mining and Environmental Engineering, University of Wollongong, Wollongong, NSW 2522, Australia

${ }^{\mathrm{b}}$ Sydney Water Corporation, Parramatta, NSW 2124, Australia

* Corresponding author: Long Duc Nghiem, Email: longn@uow.edu.au; Ph +61 242214590 


\begin{abstract}
This study aims to evaluate the use of oxidation reduction potential (ORP) to regulate the injection of a small amount of oxygen into an anaerobic digester for reducing $\mathrm{H}_{2} \mathrm{~S}$ concentration in biogas. The results confirm that micro-oxygen injection can be effective for controlling $\mathrm{H}_{2} \mathrm{~S}$ formation during anaerobic digestion without disturbing the performance of the digester. Biogas production, composition, and the removal of volatile solids (VS) and chemical oxygen demand (COD) were monitored to assessment the digester's performance. Six days after the start of the micro-oxygen injection, the ORP values increased to between 320 to $-270 \mathrm{mV}$, from the natural baseline value of $-485 \mathrm{mV}$. Over the same period the $\mathrm{H}_{2} \mathrm{~S}$ concentration in the biogas decreased from over 6,000 ppm to just $30 \mathrm{ppm}$. No discernible changes in the VS and COD removal rates, $\mathrm{pH}$ and alkalinity of the digestate or in the biogas production or composition were observed.
\end{abstract}

Keywords: Anaerobic digestion, micro-aeration, hydrogen sulphide, biogas, Oxidation Reduction Potential (ORP).

\title{
1. Introduction
}

Anaerobic digestion is the most widely used technique for treating sewage sludge in medium and large wastewater treatment plants (Brisolara and Qi, 2013; Jenicek et al., 2012; Jenicek et al., 2010; Wang et al., 2013). Anaerobic digestion is also widely used for the treatment of organic waste materials such as agro-waste and the putrescible fraction of municipal solid wastes (Karthikeyan and Visvanathan, 2013). During anaerobic treatment, organic materials in the sludge are transformed to biogas which comprises mostly methane and carbon dioxide. During this process, substantial reductions in the quantity of pathogenic organisms can be achieved. As readily biodegradable solids, known as volatile solids (VS), are substantially removed by anaerobic digestion, the final product is stable and can be suitable for agricultural use (Brisolara and Qi, 2013). If captured, the biogas produced from anaerobic digestion is a form of renewable fuel and can be used for heat and electricity generation to off-set the energy input into wastewater treatment (Jenicek et al., 2012).

During anaerobic digestion, sulphur is reduced to hydrogen sulphide $\left(\mathrm{H}_{2} \mathrm{~S}\right)$. In general, $\mathrm{H}_{2} \mathrm{~S}$ concentration in biogas obtained from the anaerobic digestion of wastewater sludge is in the range between 1,000 to $2,400 \mathrm{ppm}$. $\mathrm{H}_{2} \mathrm{~S}$ concentrations of up to $10,000 \mathrm{ppm}$ have also been reported in some cases (Wellinger and Linberg, 2000). The occurrence of $\mathrm{H}_{2} \mathrm{~S}$ in biogas can significantly reduce its economic value and reuse potential because oxidised sulphur 
compounds can be very corrosive in the presence of water. $\mathrm{H}_{2} \mathrm{~S}$ is also extremely reactive with most metals and the reactivity can be increased by pressure, temperature, and the presence of water. Therefore, before biogas can be used $\mathrm{H}_{2} \mathrm{~S}$ must be removed or at least reduced to minimise corrosion in compressors, gas storage tanks and engines (Wellinger and Linberg, 2000).

In practice, $\mathrm{H}_{2} \mathrm{~S}$ removal from biogas has been achieved by various physical, chemical and biological processes. These include the use of dry or wet adsorbent (also known as dry or wet scrubbing), membrane separation, chemical precipitation using metal salts (such as iron chloride) and biological scrubbing. However, these types of post-treatment of biogas to remove $\mathrm{H}_{2} \mathrm{~S}$ can be energy intensive and expensive. The cost of replacing the adsorbent 'scrubbing' media in a typical wastewater treatment plant of about $50 \mathrm{ML} / \mathrm{d}$ in capacity to achieve a $\mathrm{H}_{2} \mathrm{~S}$ concentration in biogas of less than $400 \mathrm{ppm}$ is around $\mathrm{AU} \$ 100,000$ a year. Given the high cost of post-treatment $\mathrm{H}_{2} \mathrm{~S}$ removal, there has been a significant research interest to develop in-situ techniques to control and reduce the formation of $\mathrm{H}_{2} \mathrm{~S}$ during the digestion process. A notable technique that could cost-effectively reduce $\mathrm{H}_{2} \mathrm{~S}$ formation and hence concentration of $\mathrm{H}_{2} \mathrm{~S}$ in biogas is micro-aeration (Díaz et al., 2011a; Díaz and FdzPolanco, 2012; Díaz et al., 2011b; Díaz et al., 2010; Díaz et al., 2011c; Duangmanee, 2009; Fdz.-Polanco et al., 2009; Khanal and Huang, 2006).

Micro-aeration is the controlled introduction of a minute amount of oxygen or air into an anaerobic digester while maintaining anaerobic conditions. This enables anaerobic digestion of organic waste to continue while reducing the potential for $\mathrm{H}_{2} \mathrm{~S}$ formation. The effectiveness of micro-aeration for controlling $\mathrm{H}_{2} \mathrm{~S}$ in biogas has been demonstrated by a number of laboratory scale investigations (Díaz et al., 2011a; Díaz and Fdz-Polanco, 2012; Díaz et al., 2011b; Díaz et al., 2010; Díaz et al., 2011c; Duangmanee, 2009; Fdz.-Polanco et al., 2009; Khanal and Huang, 2006). Short term full scale demonstration of micro-aeration to reduce $\mathrm{H}_{2} \mathrm{~S}$ concentration in biogas has also been reported (Jenicek et al., 2008). Microaeration can oxidise $\mathrm{H}_{2} \mathrm{~S}$ to elementary sulphur or prevent the reduction of sulphur into $\mathrm{H}_{2} \mathrm{~S}$. The oxidisation of $\mathrm{H}_{2} \mathrm{~S}$ to elementary sulphur utilises a consortium of sulphur-oxidising microorganisms such as Thiobacillus to oxidise sulphide to elementary sulphur. These sulphur-oxidising microorganisms are ubiquitously present in anaerobic digestion, so their inoculation to the system is not required (Wellinger and Linberg, 2000). As most of them are autotrophic, they can use the carbon dioxide in biogas as a carbon source (Wellinger and 
Linberg, 2000). Hence they have the potential to improve production rate and composition of biogas from anaerobic digestion.

It has also been suggested that the reduction of sulphur into $\mathrm{H}_{2} \mathrm{~S}$ is prohibited under a microaeration condition. Indeed, there exists a redox potential window that is inhibitory to the formation of $\mathrm{H}_{2} \mathrm{~S}$ but not $\mathrm{CH}_{4}$. The oxidation reduction potential (ORP) is a measure of the redox potential and is sensitive to the presence of $\mathrm{O}_{2}$ in an aqueous solution. Thus, ORP can be used to define the condition of biochemical reactions. The optimum ORP for $\mathrm{CH}_{4}$ reducing bacteria is below $-230 \mathrm{mV}$ while an ORP value above $-280 \mathrm{mV}$ is inhibitory to sulphate reducing bacteria (Duangmanee, 2009; Hungate, 1969).

Although it is still not clear which of the two above mentioned mechanisms is dominant, both requires the introduction of a minute amount of oxygen $\left(\mathrm{O}_{2}\right)$ to the digester. However, introducing oxygen into an anaerobic environment is risky both from safety and digester performance perspectives. Thus, in this study, we propose to use ORP to regulate the oxygen injection to create a micro-aeration condition for controlling $\mathrm{H}_{2} \mathrm{~S}$ formation. It is also noted that while the effectiveness of micro-oxygen injection aeration to reduce $\mathrm{H}_{2} \mathrm{~S}$ concentration in biogas has been confirmed by many laboratory scale studies, practical demonstration of this approach at pilot or full scale level has not been demonstrated.

A review of literature, suggests that all previous studies, except one (Khanal and Huang, 2006), have relied on the $\mathrm{O}_{2}$ to $\mathrm{S}^{2-}$ molar ratio or the $\mathrm{H}_{2} \mathrm{~S}$ concentration in biogas to determine the volume of $\mathrm{O}_{2}$ to be injected into the digester. Our literature review indicates that the optimum $\mathrm{O}_{2}$ to $\mathrm{S}^{2-}$ molar ratio is between 0.3 to 1.0 (Duangmanee, 2009). In a recent study, Ramos and Fdz-Polanco (2014) have successfully used the $\mathrm{H}_{2} \mathrm{~S}$ concentration in biogas (measured by a micro GC) to control the rate of $\mathrm{O}_{2}$ injection. However, both of these methods are not practical because $\mathrm{O}_{2}$ over loading can disrupt the anaerobic process. Therefore, this study aim to develop and trial a technique that can be readily retrofitted into an existing plant to reduce $\mathrm{H}_{2} \mathrm{~S}$ concentration in biogas using controlled oxygen injection.

\section{Materials and methods}

\subsection{Anaerobic digesters}

Two anaerobic digesters were used in parallel. Each digester consisted of an anaerobic reactor, a mechanical mixer, feed and circulation pumps and a gas holder. The active volume of the reactor was $50 \mathrm{~L}$ with a head space of about $20 \mathrm{~L}$. A Supervisory Control and Data 
Acquisition (SCADA) system was used to control both digesters. A detailed description of these anaerobic digesters is available elsewhere (Nghiem et al., 2014). ORP was measured using an ORP probe inserted into the anaerobic reactor just below the sludge level. This probe was connected to the SCADA system for data acquisition and system control. In this study, Digester 1 was chosen as the control, while Digester 2 was used for evaluating the micro-oxygen injection. Apart from additional oxygen injection equipment to Digester 2, both experimental systems were identical. Oxygen injection equipment attached to Digester 2 included an oxygen bottle with a flow regulator, an electrically actuated ball valve and an oxygen diffuser. Oxygen was supplied to the diffuser from a pressurised oxygen bottle via an electrically actuated ball valve. The ball valve opened or closed according to signal from the SCADA system to maintain the ORP level between -310 and $-290 \mathrm{mV}$. A schematic diagram of digester 2 is shown in Figure 1.

\section{[FIGURE 1]}

\subsection{Monitoring and measurement}

Biogas flow rate, digester temperature, ORP, and pressure were monitored in real time and recorded by the SCADA system. Biogas composition $\left(\mathrm{CH}_{4}, \mathrm{CO}_{2}, \mathrm{H}_{2} \mathrm{~S}\right.$, and $\left.\mathrm{O}_{2}\right)$ was measured daily using a portable biogas analyser (Biogas 5000, Geotech, UK). The gas holder was emptied at the end of each working day. Biogas is allowed to accumulate in the gas holder overnight and one litre biogas sample was taken for analysis at the beginning of the following day. Total solids (TS), volatile solids (VS), chemical oxygen demand (COD), and alkalinity of the raw and digested sludge samples were taken every three to six days and were analysed according to the standard method. $\mathrm{pH}$ was measured at the time of sample collection. The

removal rates of COD and VS were calculated by $R=100 \times\left(1-\frac{C_{D}}{C_{F}}\right)$ in which, $\mathrm{C}_{\mathrm{D}}$ and $\mathrm{C}_{\mathrm{F}}$ are VS or COD of the digestate and feed.

\subsection{Basic operation of the anaerobic digesters}

Both anaerobic digesters were seeded using anaerobically digested sludge from a full scale wastewater treatment plant in Sydney Australia. They were fed with raw primary sludge obtained from the same plant on a semi-continuous basis.

The pilot digester was fed every hour and was controlled by a SCADA system. COD and TS content and the VS/TS ratio of the primary sludge were $46.3 \pm 10.2 \mathrm{~g} / \mathrm{L}, 3.5 \pm 0.6 \%, 84.8 \pm$ 
$4.6 \%$, respectively. Each hour, $104 \mathrm{~mL}$ of sludge from the digester was wasted and then the same volume of primary sludge was pumped into the digester to avoid short-circuiting. The process of sludge wasting and feeding lasted 18 seconds each. The daily feed volume was 2.5 L/day, corresponding to a hydraulic retention time of 20 days. Throughout the experiments, both digesters were operated at $35.0 \pm 0.2{ }^{\circ} \mathrm{C}$.

Biogas samples taken during acclimatisation, showed that the concentration of $\mathrm{H}_{2} \mathrm{~S}$ in biogas for both pilot digesters was less than $200 \mathrm{ppm}$. By comparison the typical $\mathrm{H}_{2} \mathrm{~S}$ concentration in biogas at the plant is between 1,000 to $2,400 \mathrm{ppm}$. It was noted at the time that the discrepancy in $\mathrm{H}_{2} \mathrm{~S}$ concentration in biogas between the pilot and full scale digesters could have been attributed to repair work occurring on the primary treatment system at the time of this study. Therefore, to simulate typical $\mathrm{H}_{2} \mathrm{~S}$ concentrations in the biogas, $20 \mathrm{mM}$ of sulphate (in the form of analytical grade $\mathrm{MgSO}_{4} .7 \mathrm{H}_{2} \mathrm{O}$ ) was added to the feed. $\mathrm{H}_{2} \mathrm{~S}$ concentrations in the biogas during the acclimatisation stage peaked at 4,400 ppm in Digester 1 and 6,000 ppm in Digester 2. The exact reason for this discrepancy in $\mathrm{H}_{2} \mathrm{~S}$ concentration between the two digesters is not known. Once these high $\mathrm{H}_{2} \mathrm{~S}$ concentrations were reached seeding with sulphate ceased and the systems were left to stabilise.

\subsection{Micro-oxygen injection}

Once $\mathrm{H}_{2} \mathrm{~S}$ concentrations increased and stabilised, micro-oxygen injection could commence. A medical grade oxygen bottle was used to inject oxygen into the digester at $0.14 \mathrm{~mL} / \mathrm{s}$. The volume of oxygen injected directly into the digester was controlled using an electrically actuated ball valve connected to the SCADA system (Figure 1). SCADA was programmed to open and close the valve when the ORP value reached $-310 \mathrm{mV}$ and $-290 \mathrm{mV}$, respectively. The oxygen entered the digester through a ceramic diffuser $(6 \mathrm{~cm} \times 10 \mathrm{~cm})$ placed at the base of the reactor. The discharge pressure of the oxygen bottle was controlled using a flow regulator set to $150 \mathrm{kPa}$.

\section{Results and discussion}

\subsection{General performance of the anaerobic digesters}

The two digesters were operated under the same condition for more than one month to establish the baseline for subsequent comparison. Biogas production, composition, and ORP of both digesters were stable during the acclimatisation period (Table 1). Both alkalinity and 
acidity were stable within the range of $1,600-2,100 \mathrm{mg} / \mathrm{L}\left(\right.$ as $\left.\mathrm{CaCO}_{3}\right)$ and $\mathrm{pH} 6.9-7.1$. These alkalinity and $\mathrm{pH}$ values are consistent with the literature (Brisolara and Qi, 2013), indicating that the anaerobic digesters were in a healthy condition. Biogas productions from both digesters were also stable at $25-28 \mathrm{~mL} / \mathrm{min}$. The average volume of biogas produced in both systems were less than $10 \%$ different (Table 1). Daily gas composition measurement indicated that there were no significant changes in the proportion of methane present. Biogas from Digester 1 (the control) was $56.4 \pm 2.0 \%$ methane and $38.5 \pm 0.9 \%$ carbon dioxide. While biogas from the test digester (Digester 2), was $58.4 \pm 0.6 \%$ methane and $39.4 \pm 0.3 \%$ carbon dioxide. These values are consistent with literature (Brisolara and Qi, 2013). Prior to oxygen injection, the ORP of both digesters were $-485 \mathrm{mV}$.

\section{[TABLE 1]}

\subsection{Effects of micro-oxygen injection}

Using the hypothesis that there is an ORP window between $-310 \mathrm{mV}$ and $-290 \mathrm{mV}$ where methanogenesis can occur while $\mathrm{H}_{2} \mathrm{~S}$ formation is supressed. SCADA was set to inject oxygen into Digester 2 when the ORP value reached $-310 \mathrm{mV}$ and stop the injection when the ORP reached $-290 \mathrm{mV}$ (Figure 2).

Injection of oxygen into Digester 2 had an immediate effect on the $\mathrm{H}_{2} \mathrm{~S}$ concentration in the biogas (Figure 3). One day after a micro-aeration condition was established in Digester 2, the $\mathrm{H}_{2} \mathrm{~S}$ concentration dropped from $6,000 \mathrm{ppm}$ to $2,540 \mathrm{ppm}$ (58\% reduction). After six days, the $\mathrm{H}_{2} \mathrm{~S}$ concentration had reduced further to only $30 \mathrm{ppm}$ (>99\% reduction) which is consistent with the results previously reported by Diaz et al., (2011c). It is noteworthy that during the experiment, the equipment failed for 12 hours during which time no oxygen was injected into the digester. This event did not exert any discernible impact on the concentration of $\mathrm{H}_{2} \mathrm{~S}$ in biogas. Similar results were reported by Diaz et al., (2011c), who showed no observable impact of the short term variation in oxygen injection on $\mathrm{H}_{2} \mathrm{~S}$ removal efficiency. The results from Figures 2 and 3 are significant as ORP in an operating full scale digester can be readily measured in real time and is a far more practical approach compared to previous methods using $\mathrm{O}_{2}$ to $\mathrm{S}^{2-}$ molar ratios. In Digester 1 (the control), $\mathrm{H}_{2} \mathrm{~S}$ concentrations remained constant at around 4,000 ppm (Figure 3).

The ORP values measured in the digester had a slightly wider range $(-320 \mathrm{mV}$ and $-270 \mathrm{mV})$ than the set points. This could be attributed to the lag time between the injection of oxygen 
and a fully mixed condition. The lag may have resulted from the relatively small size of the oxygen diffuser $\left(60 \mathrm{~cm}^{2}\right)$ compared to the size of the digester (i.e. $\left.50 \mathrm{~L}\right)$.

[FIGURE 2]

[FIGURE 3]

Micro-oxygen injection did not result in any observable negative impacts on the anaerobic digestion process. The biogas flow rates of the reference digester under a strict anaerobic condition (Digester 1) and the test digester under a micro-aerobic condition (Digester 2) were similar over the course of the experiment (Figure 4). In addition, the biogas composition of both digesters remained the same throughout the experiment.

\section{[FIGURE 4]}

There are some notable fluctuations in COD and VS removals by both digesters over the experimental period (Figure 5). This is possibly because of the natural variation in the total solids (TS) content of the feed. The TS content varied significantly in the range from 1.79 to $4.55 \mathrm{~g} / \mathrm{L}$. With a hydraulic residence time (HRT) of 20 days in both pilot digesters, any variation in the feed can impact on solids removal rates. Nevertheless, the VS and COD removal rates of both digesters were comparable. The average VS and COD removal rates in Digester 1 were $46.6 \pm 16.6 \%$ and $42.4 \pm 18.0 \%$. While Digester 2 , the test digester, had slightly higher average VS and COD removal rates of $51.7 \pm 16.4 \%$ and $53.7 \pm 13.7$, which is in good agreement with a previous study by Jenecik et al., (2010). Both sets of removal rates are consistent literature for single stage mesophilic anaerobic digesters (Astals et al., 2013; Fdz.Polanco et al., 2009; Razaviarani et al., 2013).

\section{[FIGURE 5]}

\section{Conclusion}

This study demonstrates that ORP can be used as the regulating parameter to obtain a suitable micro-aeration condition for reducing $\mathrm{H}_{2} \mathrm{~S}$ concentration in biogas. Six days after the ORP was increased to the range between -320 to $-270 \mathrm{mV}$ (from the natural baseline value of $485 \mathrm{mV}$ ), $\mathrm{H}_{2} \mathrm{~S}$ in biogas decreased from over $6,000 \mathrm{ppm}$ to as low as $30 \mathrm{ppm} . \mathrm{H}_{2} \mathrm{~S}$ concentration from the reference digester (without micro-oxygen injection) was over 4,000 ppm. No discernible impacts of micro-oxygen injection on VS removal, COD removal, $\mathrm{pH}$ and alkalinity of the digestate, biogas production as well as biogas composition were observed. 


\section{Acknowledgement}

The authors wish to thank a large number of internal and external stakeholders who have contributed to Sydney Water's Digester Research Program including, but not limited to Derek Van Rys, Glenn Austin, Tung Nguyen, Tony Williamson, Bondi WWTP production officers, Wayne Jackson, Phil Woods, Brendan Galway, Sarah Vierboom and Nicola Nelson from Sydney Water. Also, Sydney Water's West Ryde Laboratory is thanked for their assistance with primary sludge and digestate analysis.

\section{Supplementary data}

Supplementary data associated with this article can be found in the online version.

\section{References}

[1] Astals, S., Esteban-Gutiérrez, M., Fernández-Arévalo, T., Aymerich, E., GarcíaHeras, J.L., Mata-Alvarez, J. 2013. Anaerobic digestion of seven different sewage sludges: A biodegradability and modelling study. Water Res., 47, 6033-6043.

[2] Brisolara, K.F., Qi, Y. 2013. Biosolids and sludge management. Water Environ. Res., $85,1283-1297$.

[3] Díaz, I., Donoso-Bravo, A., Fdz-Polanco, M. 2011a. Effect of microaerobic conditions on the degradation kinetics of cellulose. Bioresour. Technol., 102, 1013910142.

[4] Díaz, I., Fdz-Polanco, M. 2012. Robustness of the microaerobic removal of hydrogen sulfide from biogas. Water Sci. Technol., 65, 1368-1374.

[5] Díaz, I., Lopes, A.C., Pérez, S.I., Fdz-Polanco, M. 2011b. Determination of the optimal rate for the microaerobic treatment of several $\mathrm{H} 2 \mathrm{~S}$ concentrations in biogas from sludge digesters. Water Sci. Technol., 64, 233-238.

[6] Díaz, I., Lopes, A.C., Pérez, S.I., Fdz-Polanco, M. 2010. Performance evaluation of oxygen, air and nitrate for the microaerobic removal of hydrogen sulphide in biogas from sludge digestion. Bioresour. Technol., 101, 7724-7730.

[7] Díaz, I., Pérez, S.I., Ferrero, E.M., Fdz-Polanco, M. 2011c. Effect of oxygen dosing point and mixing on the microaerobic removal of hydrogen sulphide in sludge digesters. Bioresour. Technol., 102, 3768-3775.

[8] Duangmanee, T. 2009. Micro-aeration for hydrogen sulfide removal from biogas, Vol. $\mathrm{PhD}$, Iowa State University. 
[9] Fdz.-Polanco, M., Díaz, I., Pérez, S.I., Lopes, A.C., Fdz.-Polanco, F. 2009. Hydrogen sulphide removal in the anaerobic digestion of sludge by micro-aerobic processes: Pilot plant experience. Water Sci. Technol., 60, 3045-3050.

[10] Hungate, R.E. 1969. Chapter IV A Roll Tube Method for Cultivation of Strict Anaerobes. in: Methods in Microbiology, (Eds.) J.R. Norris, D.W. Ribbons, Vol. Volume 3, Part B, Academic Press, pp. 117-132.

[11] Jenicek, P., Bartacek, J., Kutil, J., Zabranska, J., Dohanyos, M. 2012. Potentials and limits of anaerobic digestion of sewage sludge: Energy self-sufficient municipal wastewater treatment plant? Water Sci. Technol., 66, 1277-1281.

[12] Jenicek, P., Keclik, F., Maca, J., Bindzar, J. 2008. Use of microaerobic conditions for the improvement of anaerobic digestion of solid wastes. in: Water Science and Technology, Vol. 58, pp. 1491-1496.

[13] Jenicek, P., Koubova, J., Bindzar, J., Zabranska, J. 2010. Advantages of anaerobic digestion of sludge in microaerobic conditions. Water Sci. Technol., 62, 427-434.

[14] Karthikeyan, O.P., Visvanathan, C. 2013. Bio-energy recovery from high-solid organic substrates by dry anaerobic bio-conversion processes: A review. Rev. Environ. Sci. Biotechnol., 12, 257-284.

[15] Khanal, S.K., Huang, J.C. 2006. Online oxygen control for sulfide oxidation in anaerobic treatment of high-sulfate wastewater. Water Environ. Res., 78, 397-408.

[16] Nghiem, L.D., Nguyen, T.T., Manassa, P., Fitzgerald, S., Dawson, M., Vierboom, S. 2014. Co-digestion of sewage sludge and crude glycerol for on-demand biogas production. Int. Biodeter. Biodegr., Accepted 29 April 2014.

[17] Ramos, I., Fdz-Polanco, M. 2014. Microaerobic control of biogas sulphide content during sewage sludge digestion by using biogas production and hydrogen sulphide concentration. Chem. Eng. J., 250, 303-311.

[18] Razaviarani, V., Buchanan, I.D., Malik, S., Katalambula, H. 2013. Pilot scale anaerobic co-digestion of municipal wastewater sludge with biodiesel waste glycerin. Bioresour. Technol., 133, 206-212.

[19] Wang, M., Sahu, A.K., Rusten, B., Park, C. 2013. Anaerobic co-digestion of microalgae Chlorella sp. and waste activated sludge. Bioresour. Technol., 142, 585590.

[20] Wellinger, A., Linberg, A. 2000. Biogas Upgrading and Utilization. IEA Bioenergy. 


\section{List of Tables}

Table 1: Baseline performance of both digesters.

\begin{tabular}{|l|c|c|c|c|c|c|}
\hline \multirow{2}{*}{ Parameter } & \multicolumn{3}{|c|}{ Digester 1 } & \multicolumn{3}{c|}{ Digester 2 } \\
\cline { 2 - 7 } & Average & Max & Min & Average & Max & Min \\
\hline ORP $(\mathrm{mV})$ & -485 & -470 & -494 & -485 & -482 & -490 \\
\hline Biogas production $(\mathrm{mL} / \mathrm{min})$ & 28.1 & 32.4 & 25.1 & 25.6 & 28.3 & 21.3 \\
\hline $\mathrm{CH}_{4}$ content $(\%)$ & 55.5 & 58.5 & 49.8 & 58.4 & 59.4 & 56.1 \\
\hline $\mathrm{CO}_{2}$ content $(\%)$ & 38.1 & 39.5 & 35.9 & 39.2 & 41.1 & 34.8 \\
\hline $\mathrm{H}_{2} \mathrm{~S}$ content $(\mathrm{ppm})$ & 126.8 & 200 & 91 & 25.5 & 60 & 12 \\
\hline
\end{tabular}




\section{List of Figures}

Figure 1: Schematic diagram of digester 2 with additional equipment required for microaeration.

Figure 2: ORP values as a function of time during the micro-aeration experiment.

Figure 3: Evolution of the $\mathrm{H}_{2} \mathrm{~S}$ concentration in biogas from the two digesters.

Figure 4: Biogas flow rate as a function of time during the micro-aeration experiment.

Figure 5: (a) VS removal and (b) COD removal as a function of time. 


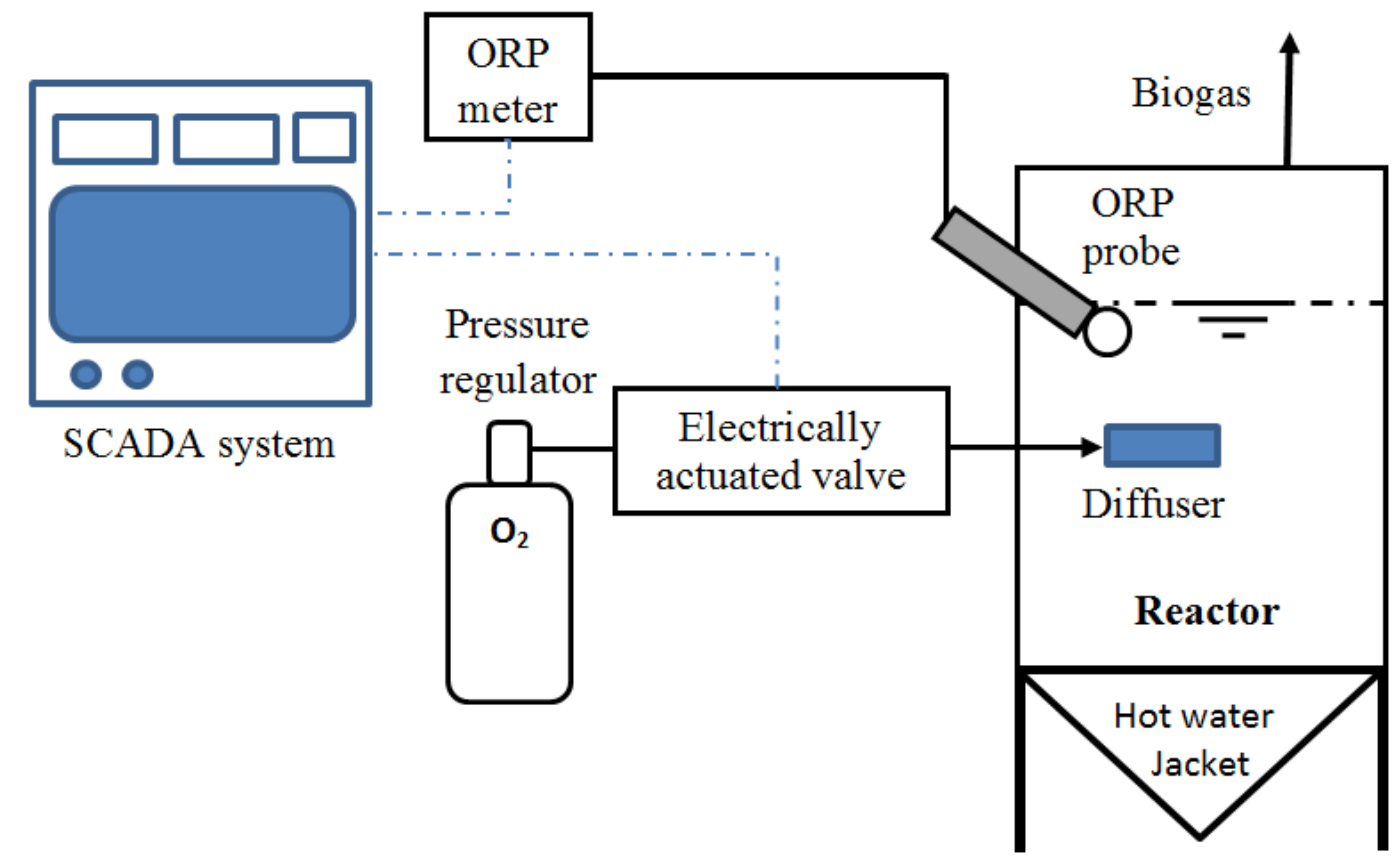

Figure 1

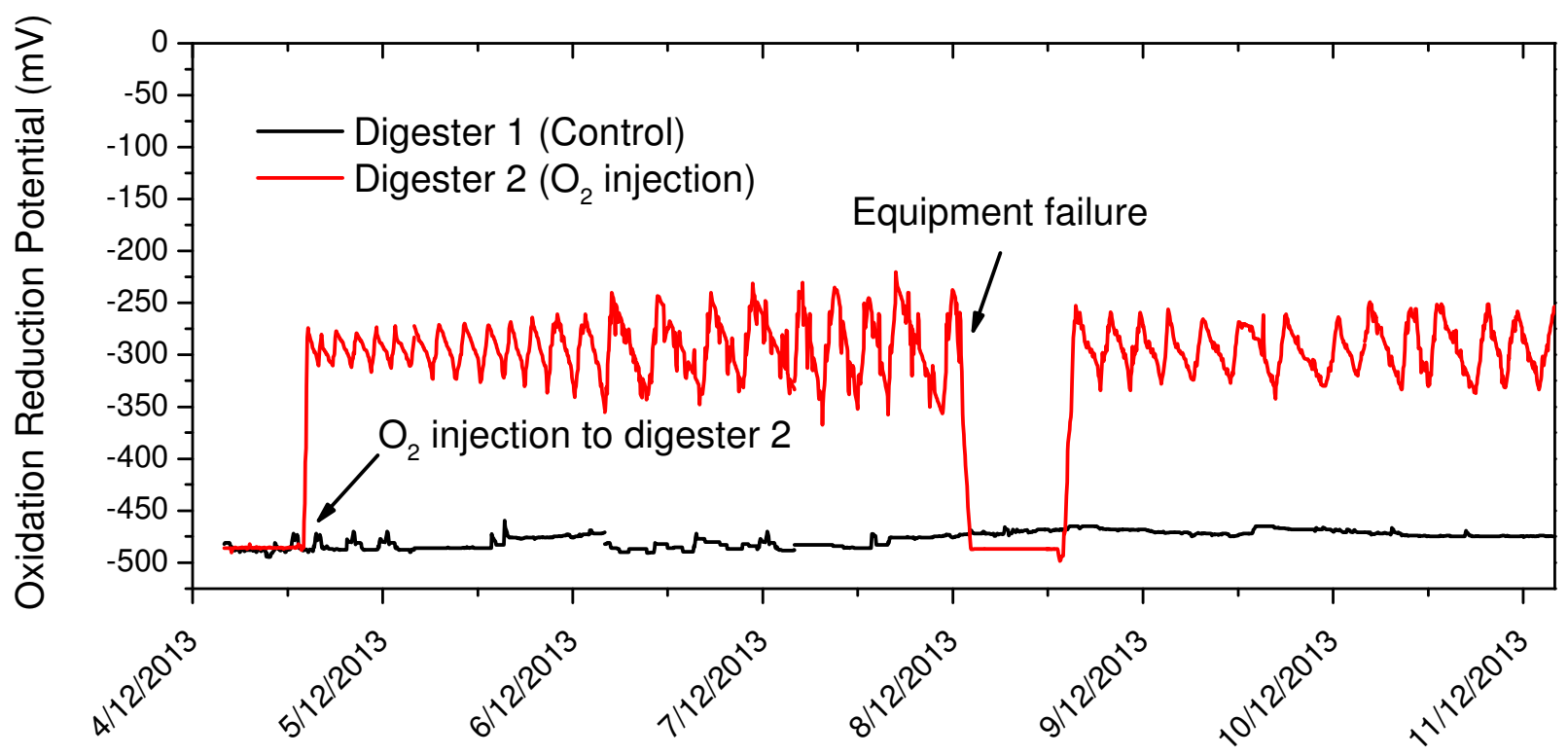

Figure 2 


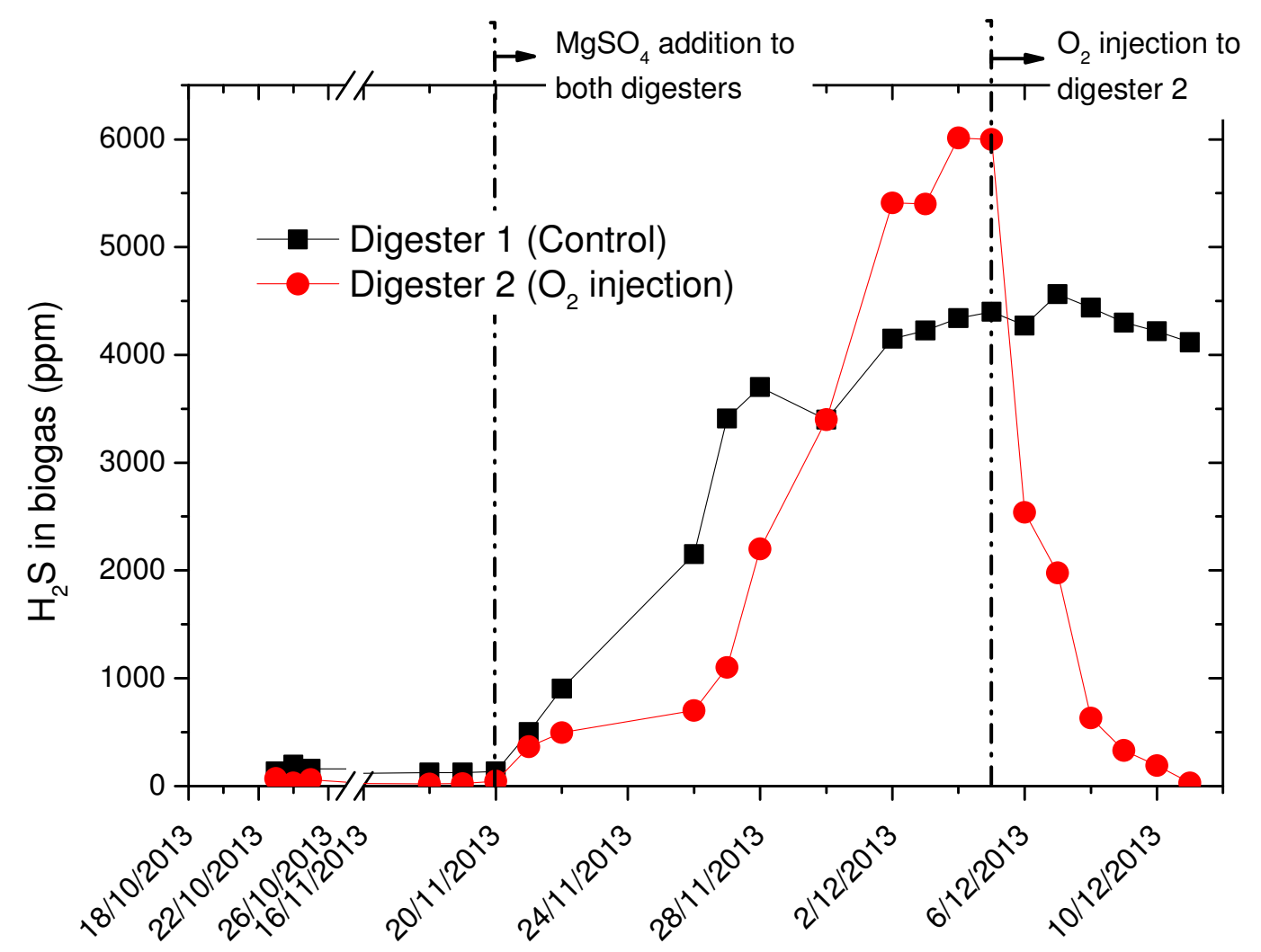

Figure 3

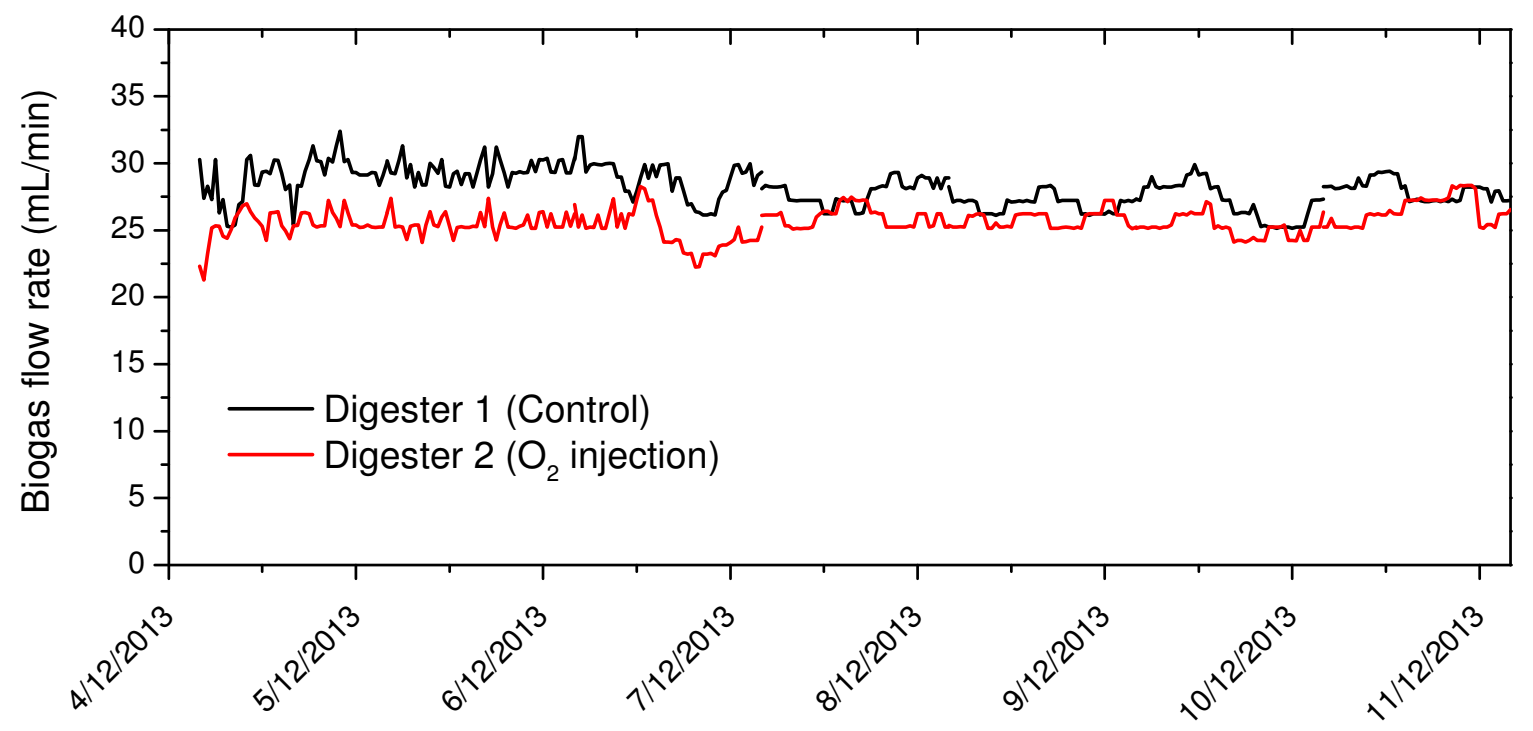

Figure 4 

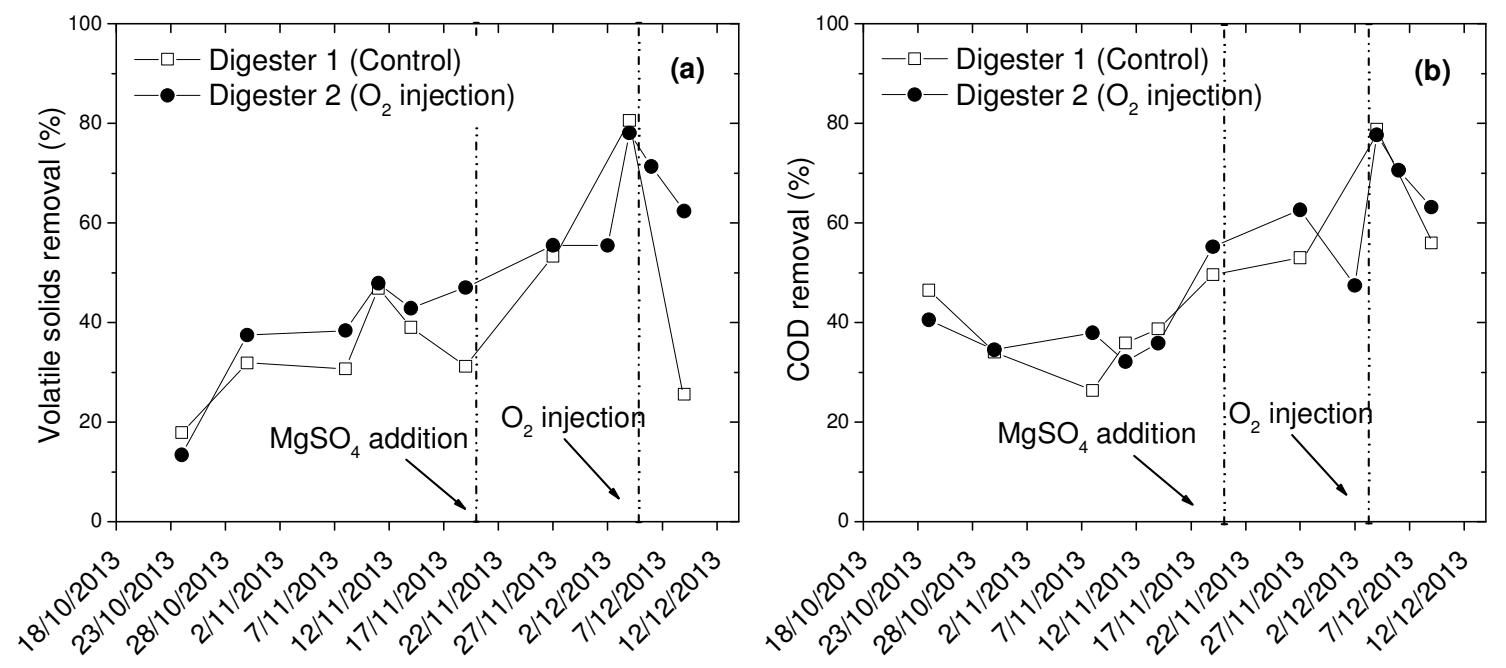

Figure 5 